\title{
Status, Trends, and Advances in Earthworm Research and Vermitechnology
}

\section{Natchimuthu Karmegam, ${ }^{1}$ Radha D. Kale, ${ }^{2,3}$ Thilagavathy Daniel, ${ }^{4}$ M. Nurul Alam, ${ }^{5}$ and Martín Gerardo Rodríguez}

\author{
${ }^{1}$ Department of Biotechnology, VMKV Engineering College, Salem, Tamil Nadu 636 308, India \\ ${ }^{2}$ Department of Entomology, University of Agricultural Sciences (GKVK), Bangalore 560 065, India \\ ${ }^{3}$ Centre for Scientific Research and Advanced Learning, Mount Carmel College, Bangalore 560 052, India \\ ${ }^{4}$ Department of Biology, Gandhigram Rural University, Gandhigram, Tamil Nadu 624 302, India \\ ${ }^{5}$ Department of Crop Science and Technology, University of Rajshahi, Rajshahi 6205, Bangladesh \\ ${ }^{6}$ Physiology, Pharmacology and Toxicology Department, Center of Basic Sciences, Autonomous University of Aguascalientes, \\ 20100 Aguascalientes, AGS, Mexico
}

Correspondence should be addressed to Natchimuthu Karmegam, kanishkarmegam@gmail.com

Received 27 October 2010; Accepted 28 October 2010

Copyright ( $) 2010$ Natchimuthu Karmegam et al. This is an open access article distributed under the Creative Commons Attribution License, which permits unrestricted use, distribution, and reproduction in any medium, provided the original work is properly cited.

The articles in this special issue reflect the developments in the fields of earthworm research and vermitechnology. Charles Darwin's observation on earthworms is a milestone in understanding the soil biology and enormous contribution to some aspects of the genesis of humus and of its role in soils. Earthworms are the best known soil inhabiting animals commonly called "friends of farmers" due to the beneficial role they play in soil. The research on earthworms has gained importance in India as well as in other countries. In the year 1981, an international symposium entitled Earthworm Ecology: Darwin to Vermiculture was held at Cumbria, UK, to commemorate the centenary celebration of Darwin's book The Formation of Vegetable Mould through the Action of Worms, with Observations on Their Habits that was published in 1881 by Murray, London, UK. In the year 2000, Vermillenium - an international workshop and symposium - was held at Kalamazoo, USA, to realize the progress achieved in this field after a decade (since 1991). Recently, Ninth International Symposium on Earthworm Ecology (ISEE-9) that was held at Xalapa, Mexico, during the 5 th to 10th of September 2010 clearly proved the importance of earthworms and vermitechnology by the participation of scientists from different countries. About 300 papers were received from the researchers across the world.
Considerable research is in progress with regard to significant role of earthworms and vermitechnology. This issue addresses the existing situations by providing complete, collective, and up-to-date knowledge and recent trends. It is a compilation of research articles on ecology, behavior, and functional role of earthworms at organismic levels. There are also papers to highlight the cellular and molecular studies.

The first paper by U. Kutschera and J. M. Elliott points out the origin of earthworm research from the time of Darwin (1881) that was responsible for the recent developments in biogeographical studies. A very interesting point is about the lineage of the earthworms described in this paper.

K. R. Butt and N. Grigoropoulou have given a detailed description on the tools and methods to be adopted for studying the earthworms at field level. Their contribution supports a number of suitable ecological methods and access to various tools to support earthworm research.

The paper by R. D. Kale and N. Karmegam highlights the research carried out by different scientists in India on aspects of earthworm population dynamics and species diversity associated with other soil fauna and microflora. The paper also deals with the importance of earthworm activity on physicochemical properties of soil with reference to India and other tropical countries. They laid stress 
on the earthworm plant association and importance of the secretions of earthworms as plant growth stimulators and their role as bioindicators. Several other papers on earthworm ecology are also included. The review article on the role of earthworms in soil fertility maintenance through the production of biogenic structures explains the effect of farming practices on earthworm population ( $\mathrm{T}$. Bhadauria and K. G. Saxena). P. Bescansa et al. have reported the casting activity of an anecic earthworm, Scherotheca gigas in no tillage Mediterranean soils (Ebro Valley in Navarre, NE, Spain) and its role in organic matter incorporation. Influence of the earthworm on aridity factors is also discussed. This study gives an evidence for incorporation of organic matter and in particular the most labile fractions to the soil by S. gigas. M. Birkas and coauthors have reported that the earthworm density in Hungary is directly linked to physical characteristics and soil mulch. The same may hold good even for other geographical regions.

Nitrous oxide $\left(\mathrm{N}_{2} \mathrm{O}\right)$ emission has been the threat for climatic changes. N. K. Evers and his coworkers have shown the direct correlation between density of earthworm (Lumbricus terrestris L.) population and soil moisture content to $\mathrm{N}_{2} \mathrm{O}$ emissions in a controlled greenhouse experiments. They are of the opinion that the benefits that are normally seen from earthworms in agricultural systems may be masked by their influence on facilitating the production of $\mathrm{N}_{2} \mathrm{O}$ and in turn climate change. But various other factors like the associated microorganisms, and the levels of organic matter, soil porosity for oxygen supply to soil layers have to be studied in soils with and without earthworms to derive at any conclusion. There is sufficient scope to further the research in this regard.

The influence of earthworms on plant growth may vary depending on soil structure. K.-R. Laossi and coauthors in their review article have suggested the experimental approaches to be developed to assess the influence of soil type on response of plants in the presence of earthworms. This line of study is very essential to relate the animal, plant, and edaphic factors.

Soil community is a complex food web. Earthworms, being the major macro fauna, contribute to modification of the structure and functions of different decomposers and predators. The research paper of C. Villenave et al. depicts the changes that occur in the abundance of bacterial and fungal feeding nematodes in presence of the earthworm, Pontoscolex corethrurus.

The agrochemicals are known to have adverse effect at different levels on life and activities of soil organisms including earthworms. Two papers that appear in this issue describe the effect of pesticides and herbicide on growth and reproduction of earthworms (S. Yasmin and D. D'Souza) on population growth and on histology and reproduction of Eisenia fetida, respectively (M. Gobi and P. Gunasekaran).

Probably, earthworms are the most promising sources to combat various physiological and pathological disorders that are disturbing the human life in the near future. One such product from earthworms is the protease enzyme. In this regard, the extensive review on earthworm protease compiled by R. Pan et al. gives an impetus to further research on biomolecules that have significance in pharmacological applications.

Finally, the molecular approach at DNA level is an important contribution to use earthworms as the tool to understand the possible damage that can be caused by different metallic pollutants. These are entering into the food chains of higher animals including humans. Many of these pollutants at different levels may cause damage to DNA which may be cancerous. It is inspirable from the study of T. Hirano and K. Tamae that the earthworms can also be used as model organisms for studying the carcinogenesis.

Though more articles were expected on vermicomposting and related studies, only one paper on nutrient status of vermicompost derived from urban green waste was submitted for publication. It is a comparative study to identify the most efficient epigeic earthworm (S. Pattnaik and M. V. Reddy).

The organization of the papers in this special issue represents the landmark of earthworm and vermitechnology research. Altogether the articles presented provide the reader with descriptions of earthworm ecology and different approaches to study their role in ecosystems, physiology at cellular level, and finally the vermicomposting. We hope that this issue would provide the resources necessary to understand and to promote advances in this important field.

We hope that the readers and the research workers will find this as a useful source of information. We would like to thank the reviewers who helped us in reviewing the articles and timely recommendations. We also would like to thank the Chief-Editor, Dr. Siobhán Staunton, Director of Research from Ecologie Fonctionnelle et Biogéochimie des Sols (Montpellier Cedex, France), and other staff of the Editorial Section of Applied and Environmental Soil Science (AESS), who had faith in us and cooperated at all stages of compilation. Special thanks are due to Dr. Nada Ahmed who had coordinated all communications at all stages of compilation of this special issue.

\author{
Natchimuthu Karmegam \\ Radha D. Kale \\ Thilagavathy Daniel \\ M. Nurul Alam \\ Martín Gerardo Rodríguez
}



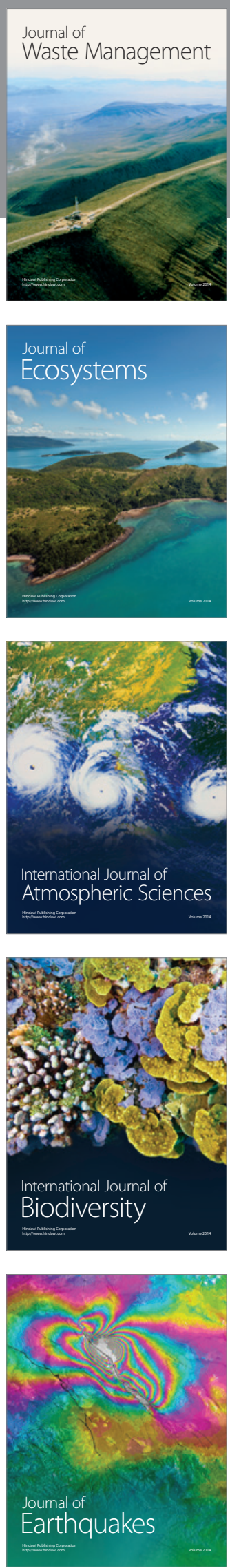
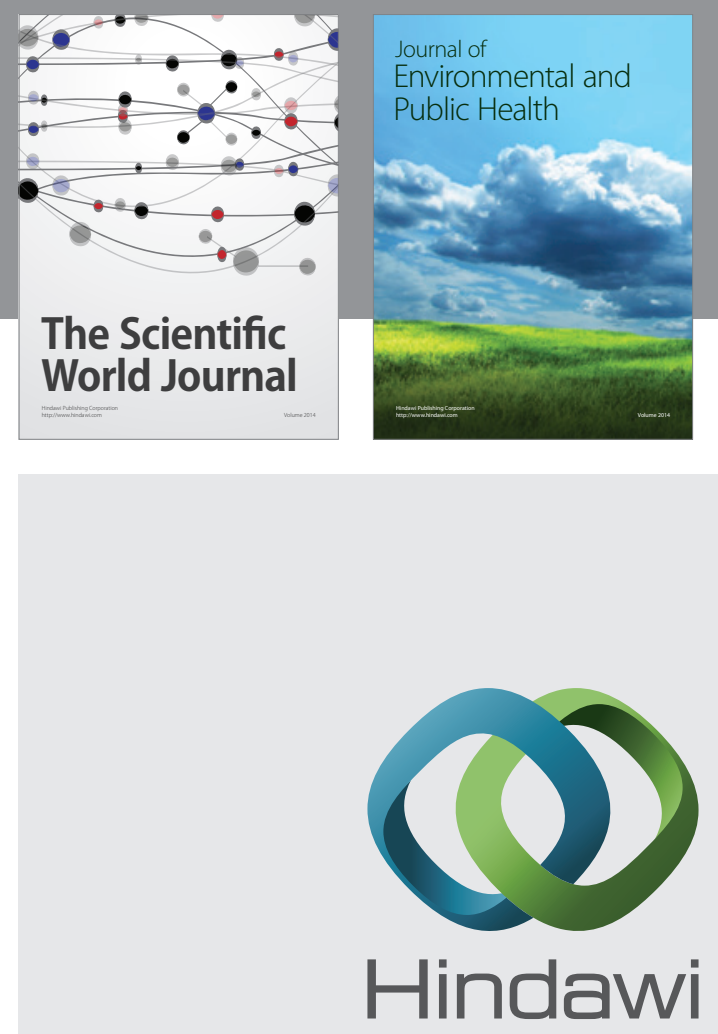

Submit your manuscripts at

http://www.hindawi.com
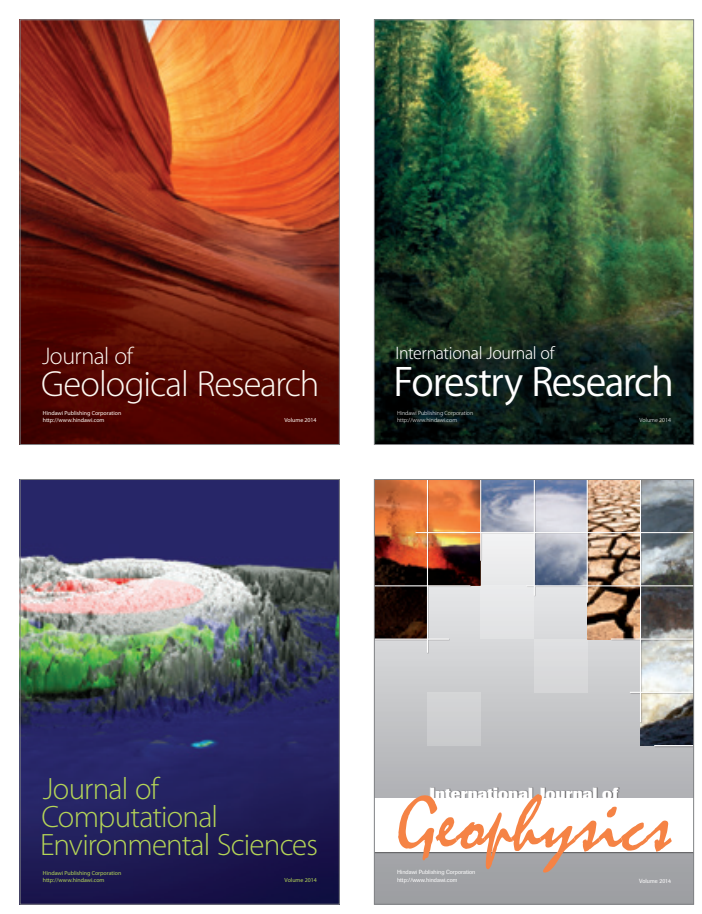
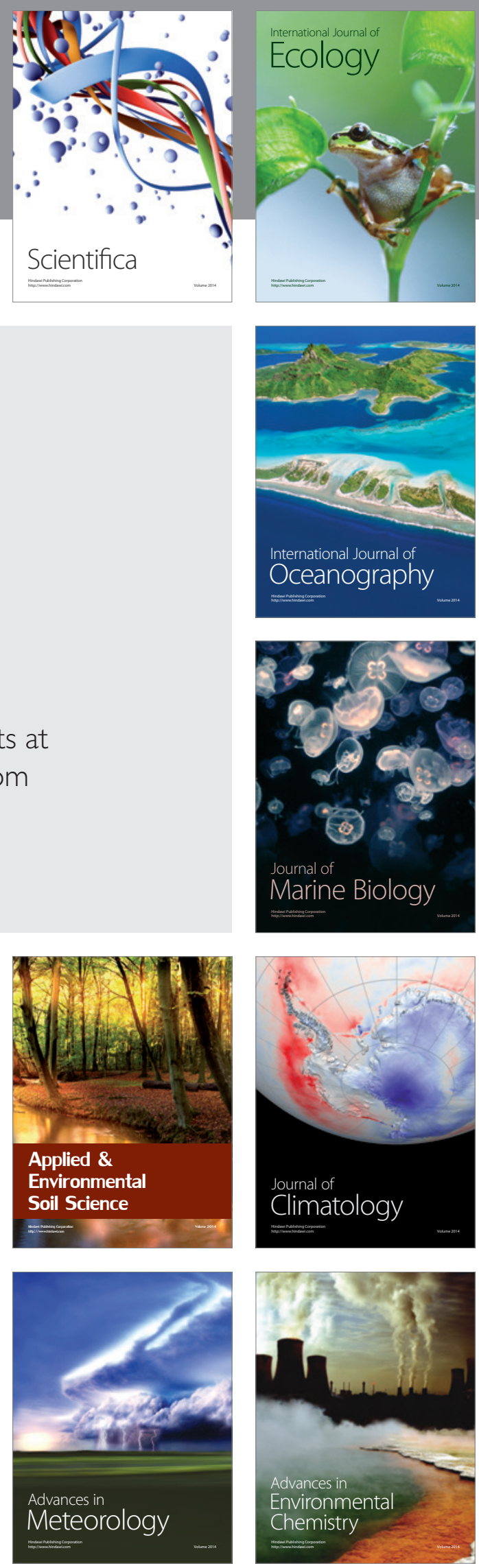